\title{
STUDI KEMAMPUAN EKSTRAK ETANOL UMBI BAWANG LANANG HITAM (Allium sativum L.) SEBAGAI ANTIDIABETES
}

\author{
Devina Ingrid Anggraini ${ }^{1)}$, Eka Wisnu Kusuma ${ }^{\text {2) }}$,Desty Putri Pancawati ${ }^{3)}$ \\ 1,2,3 Sekolah Tinggi Ilmu Kesehatan Nasional Surakarta \\ email : devina.ia@gmail.com
}

\begin{abstract}
ABSTRAK
Diabetes melitus salah satu penyakit komorbid yang paling beresiko dan memperburuk orang yang terinfeksi COVID-19. Kontrol gula darah sangat penting untuk menjaga sistem imun tubuh. Pengobatan bahan alam untuk antidiabetes lebih digemari masyarakat. Penelitian ini dilakukan untuk mengetahui kemampuan ekstrak etanol umbi bawang lanang hitam (Allium sativum L.) dalam menurunkan kadar glukosa sebesar $50 \%$. Ekstrak umbi bawang lanang hitam (Allium sativum L.) diperoleh dengan maserasi menggunakan etanol 70\%. Skrining fitokimia menunjukkan bahwa umbi bawang lanang hitam mengandung senyawa flavonoid, polifenol dan saponin. Uji aktivitas anti diabetes dengan reagen Nelson-Somogy dianalisis menggunakan Spektrofotometer UV-Vis dengan operating time selama 25 menit dan panjang gelombang maksimum $746 \mathrm{~nm}$. Pengukuran penurunan kadar glukosa dilakukan dengan lima variasi konsentrasi yaitu 1 ppm, 2 ppm, 3 ppm, 4 ppm dan 5 ppm. Hasil penelitian menunjukkan ekstrak etanol umbi bawang lanang hitam (Allium sativum L.) memiliki kemampuan menurunkan kadar glukosa sangat kuat dengan nilai EC50 3,8790 ppm dan \%KV sebesar 0,6368\%.
\end{abstract}

Kata kunci: EC50; ekstrak etanol umbi bawang lanang hitam; nelson-somogy

\begin{abstract}
Diabetes melitus is one of the riskiest comorbid diseases and worsens the infected person COVID-19. Blood sugar control is very important to maintain the body's immune system. Natural medicine for anti-diabetes is more popular with the public.This research was conducted to determine the ethanol extract of black lanang onion tubers (Allium sativum L.) has the ability to reduce glucose levels by 50\%.Black lanang onion tubers (Allium sativum L.) macerated with $70 \%$ ethanol. The results showed that black lanang onion tubers contained flavonoids, polyphenols and saponins. The study of antidiabetic activity used the Nelson-Somogy method using a UV-Vis spectrophotometer instrument with operating time after heating for 25 minutes and a wavelength of $746 \mathrm{~nm}$. Measurement of the decrease in glucose levels using five concentrations of 1 ppm, $2 \mathrm{ppm}, 3 \mathrm{ppm}, 4 \mathrm{ppm}, 5$ ppm. The results showed ethanol extract of black lanang onion tubers (Allium sativum L.) has a very strong ability to reduce glucose levels with an EC value of $3.8790 \mathrm{ppm}$ and $\%$ KV of $0.6368 \%$.
\end{abstract}

Keywords: EC50; ethanol extract of black lanang onion tubers; nelson-somogy 


\section{PENDAHUluAN}

Coronavirus Disease 2019 (COVID19) merupakan penyakit varietas baru yang tidak pernah ada sebelumnya terjadi terhadap manusia. Penyebab penyakit tersebut yaitu virus Acute Respiratory-Syndrome Coronavirus-2 (SARS-CoV-2). Virus ini awal mula ditemukan dari Wuhan, Tiongkok pada akhir Desember tahun 2019. Kasus angka mortalitas COVID-19 mencapai $2,3 \%$ di seluruh dunia sedangkan khusus di kota Wuhan adalah 4,9\%, dan di provinsi Hubei 3,1\% (Huang dkk., 2020). COVID-19 mudah menginfeksi semua orang terutama usia lanjut dan yang memiliki penyakit bawaan (komorbid) lebih beresiko dan menyebabkan keadaan komplikasi lebih buruk akibat penyakit ini.

Diabetes melitus merupakan penyakit bawaan (komorbid) pada kasus covid 19 yang menduduki peringkat kedua setelah hipertensi dan memiliki angka kematian tiga kali lipat dibandingkan pasien yang tidak memiliki penyakit komorbid (Amelia dkk., 2020). Prognosis penderita COVID-19 dan diabetes melitus tergolong buruk, maka peluang hidup lebih rendah dibandingkan penderita tanpa diabetes melitus. Jika seorang penderita diabetes melitus menderita hiperglikemia akan terjadi penurunan produksi sitokin proinflamasi, yang akan merusak peranan sistem. Sindrom metabolik juga merusak fungsi makrofag dan limfosit yang turut membuat sistem imun melemah (Wang dkk., 2020).

Penggunaan bahan alam sebagai peningkat sistem imun dan antidiabetes sekarang lebih digemari masyarakat karena tidak memiliki efek samping yang serius seperti bahan sintetik. Jenis bahan alam yang yang diprediksi memiliki potensi sebagai antidiabetes yaitu umbi bawang lanang hitam (Allium sativum L.).

Bawang lanang hitam (Allium sativum L.) yaitu bawang lanang putih yang melalui proses fermentasi dengan suhu $60-70^{\circ} \mathrm{C}$ dengan kelembaban sebesar $80-90 \%$. Kandungan senyawa kimia bawang lanang hitam meningkat selama proses pemanasan terutama polifenol, flavonoid dan senyawa antioksidan lainnya. karena terjadi reaksi Maillard (Kimura dkk., 2017). Penelitian (Zhafira, 2019) menunjukkan bahwa aktivitas antioksidan dari bawang lanang hitam (Allium sativum L.) mempunyai nilai $\mathrm{IC}_{50}$ tertinggi yaitu $3,474 \mathrm{mg} / \mathrm{g}$ dengan proses farmentasi selama 12 hari. Nilai $\mathrm{IC}_{50}$ umbi bawang lanang hitam (Allium sativum L.) $<50$ ppm maka artinya aktivitas antioksidan yang dimiliki sangat kuat. Senyawasenyawa antioksidan seperti flavonoid memiliki potensi dalam penurunan kadar glukosa. Uraian diatas mendasari penelitian ini untuk dilakukan uji aktivitas antidiabetes bawang lanang hitam (Allium sativum L.) untuk mengetahui potensi dalam menurunkan kadar glukosa.

\section{METODE PENELITIAN}

a. Alat dan Bahan

Alat yang dibutuhkan meliputi neraca analitik (Ohaus Pioneer), oven, blender, rotary evaporator, Spektofotometer UVVis (Shimadzu UV mini-1240), kuvet Hellma Analytic type No 100.600 QG Light parh lotum, tabung reaksi, beaker glass, labu ukur, pipet volume, mikropipet, dan push ball.

Bahan yang dibutuhkan meliputi umbi bawang lanang hitam (Allium sativum L.), etanol 70\%, $\mathrm{NaOH}$, reagen Mayer, $\mathrm{HCl} 2 \mathrm{~N}$, reagen Dragendorff, $\mathrm{H}_{2} \mathrm{SO}_{4}$ pekat, $\mathrm{CH}_{3} \mathrm{COOH}$ glasial, $\mathrm{FeCl}_{3}$ $10 \%$, reagen Nelson (Merck), reagen arsenomolibdat (Merck), glukosa p.a (Merck) dan aquades.

b. Pembuatan Simplisia

Sampel yang digunakan bawang lanang hitam yang telah difermentasi pada suhu $60-70^{\circ} \mathrm{C}$ selama 14 hari. Bawang lanang hitam dikupas dan dibersihkan dari kulitnya. Perajangan pada bawang lanang dihitam usahakan setipis mungkin untuk mempercepat proses pengeringan. Proses pembuatan 
serbuk bawang lanang hitam diblender dan diayak dengan pengayak No. 40.

\section{c. Proses Ekstraksi}

Serbuk umbi bawang lanang hitam ditimbang 200,0 gram kemudian tambahkan $1500 \mathrm{ml}$ pelarut etanol $70 \%$, ditutup dan dibiarkan selama 3 hari dengan pengadukan sesekali, kemudian diserkai. Ampasnya diremaserasi dengan $500 \mathrm{ml}$ pelarut etanol $70 \%$ selama 2 hari, kemudian diserkai. Ekstrak cair dipekatkan dalam rotary evaporator dengan suhu $50^{\circ} \mathrm{C}$ dan kecepatannya $150 \mathrm{rpm}$. Ekstrak etanol umbi bawang lanang hitam diuapkan kembali dalam waterbath hingga menjadi ekstrak kental.

Proses Uji Fitokimia

a. Uji Flavonoid

Larutan sampel sejumlah $2 \mathrm{~mL}$ tambahkan pereaksi $\mathrm{NaOH}$ encer. Hasil positif flavonoid jika menunjukkan terbentuknya warna kuning (Armin \& Dewi, 2011).

b. Uji Saponin

Larutan sampel sejumlah $2 \mathrm{~mL}$ tambahkan air panas $2 \mathrm{ml}$ lalu didinginkan dan 10 detik dikocok kuat. Hasil positif jika menunjukkan timbulnya buih yang tingginya $1-10 \mathrm{~cm}$ selama $<10$ menit, setelah ditambahkan 1 tetes $\mathrm{HCl} 2 \%$ buih tidak hilang(Handarini, 2014).

c. Uji Alkaloid

Larutan sampel sejumlah $2 \mathrm{ml}$ tambahkan $5 \mathrm{ml} \mathrm{HCl} 2 \mathrm{~N}$, kemudian gunakan reagen Mayer dan Dragendorf untuk pengujian. Jika positif alkaloid akan menghasilkan endapan dengan pereaksi Mayer berupa endapan putih, dan pengendapan dengan pereaksi Dragendorf berwarna merah jingga

d. Uji Tanin dan Polifenol

Larutan sampel sejumlah 2 mltambahkan 10 tetes $\mathrm{FeCl}_{3} 10 \%$. Hasil positif mengandung tanin jika terbentuk warna hijau biru atau hitam, sedangkan sampel positif mengandung polifenol jika terbentuknya warna hijau kuat, merah, biru, ungu, dan hitam

e. Uji Steroid dan Triterpenoid
Larutan sampel sejumlah $2 \mathrm{~mL}$ tambahkan 10 tetes $\mathrm{CH}_{3} \mathrm{COOH}$ glasial dan 2 tetes $\mathrm{H}_{2} \mathrm{SO}_{4}$ pekat, kemudian kocok pelan dan diamkan selama beberapa menit. Jika menunjukkan warna biru atau warna hijau, hasil positif mengandung steroid, sedangkan triterpenoid menunjukkan warna ungu atau warna merah

f. Uji Aktivitas Antidiabetes

Uji aktivitas antidiabetes dilakukan dengan pengukuran operating time, panjang gelombang maksimum, kontrol positif dan uji antidiabetes menggunakan alat spektrofotometri UV-Vis. Prosesnya diawal menentukan operating time dengan memipet $1 \mathrm{ml}$ dari larutan baku kerja glukosa 100 ppm dimasukkan pada tabung reaksi, tambahkan reagen Nelson 1,0 ml lalu tutup dengan kapas. Larutan dipanaskan 10 menit di penangas air, kemudian didinginkan selama 5 menit, kemudian dimasukan ke dalam labu ukur 5,0 ml dan tambahkan $1,0 \mathrm{ml}$ reagen arsenomolibdat ke dalam labu tersebut, kemudian diencerkan dengan aquades hingga tanda batasnya dan kocok. Larutan dimasukkan ke dalam kuvet, dan kemudian dibaca pada panjang gelombang maksimum teoritis $745 \mathrm{~nm}$ dengan interval permenit selama 40 menit hingga diperoleh absorbansi yang konstan (Wardatun dkk., 2016). Penentuan panjang gelombang maksimum perlakuan yang sama, tetapi didiamkan selama operating time 25 menit dan dibaca dalam spektrofotometer UV-Vis dengan panjang gelombang 700-780 $\mathrm{nm}$.

Pengukuran kontrol positif dibuat dengan mengambil 1,0 $\mathrm{ml}$ dari larutan baku kerja glukosa 100 ppm dimasukkan dalam tabung reaksi, tambahkan reagen Nelson 1,0 ml lalu tutup dengan kapas. Larutan dipanaskan pada penangas air selama 10 menit, kemudian didinginkan selama 5 menit, kemudian dimasukan ke dalam labu ukur 5,0 $\mathrm{ml}$ dan tambahkan reagen arsenomolibdat $1,0 \mathrm{ml}$ ke dalam labu tersebut, kemudian diencerkan dengan 
akuades hingga tanda batasnya dan kocok.

Proses uji aktivitas antidiabetes dilakukan dengan ekstrak etanol umbi bawang lanang hitam dengan seri konsentrasi 1, 2, 3, 4 dan 5 ppm dari larutan sampel kerja $100 \mathrm{ppm}$ dan ditambahkan 1,0 $\mathrm{ml}$ baku glukosa dari konsentrasi $100 \mathrm{ppm}$ dalam tabung reaksi, tambahkan reagen Nelson 1,0 ml lalu tutup dengan kapas. Larutan tersebut dipanaskan pada penangas air selama 10 menit, kemudian didinginkan selama 5 menit, kemudian tuangkan ke dalam labu ukur 5,0 $\mathrm{ml}$ dan ditambahkan reagen arsenomolibdat 1,0 $\mathrm{ml}$ ke dalam labu tersebut, kemudian diencerkan dengan akuades hingga tanda batasnya dan kocok. Larutan didiamkan selama waktu operating time 25 menit, kemudian dibaca pada spektrofotometer UV-Vis pada panjang gelombang maksimum.

\section{Analisis Data}

Absorbansi yang diperoleh dan pengukuran sampel dengan larutan standar glukosa untuk menentukan persentase penurunan kadar glukosa. Cara menggunakan rumus untuk menghitung persentase kadar penurunan glukosa :

$$
a=\frac{c-b}{c} \times 100 \%
$$

Keterangan:

$\mathrm{a}=\%$ aktivitas antidiabetes

$\mathrm{b}=$ Hasil absorbansi glukosa sisa

$\mathrm{c}=$ Hasil absorbansi kontrol positif

(Glukosa + Nelson) (Anggraini \&

Damayanti, 2019)

\section{HASIL DAN PEMBAHASAN}

a. Hasil Ekstraksi

Ekstrak umbi bawang lanang hitam (Alliun sativum L.) diperoleh dengan metode remaserasi dengan menggunakan pelarut etanol $70 \%$. Pemilihan pelarut sangat penting prinsip dasarnya like dissolves like, sifat pelarut etanol $70 \%$ yaitu polar maka cocok dalam menarik senyawa-senyawa yang sama kepolarannya seperti senyawa flavonoid. Hasil rendemen ekstrak etanol umbi bawang lanang hitam (Alliun sativum L.) sebesar 78,95\%.

Tabel 1. Hasil presentase rendemen ekstrak

\begin{tabular}{lccc}
\hline Sampel & $\begin{array}{c}\text { Berat } \\
\text { simplisia } \\
\text { kering }\end{array}$ & $\begin{array}{c}\text { Berat } \\
\text { ekstrak }\end{array}$ & $\begin{array}{c}\% \\
\text { rendemen }\end{array}$ \\
\hline Umbi & 200 & 157,9 & $78,95 \%$ \\
bawang & gram & Gram & \\
lanang & & & \\
hitam & & & \\
\hline
\end{tabular}

b. Uji Fitokimia

Hasil penelitian menunjukkan ekstrak etanol umbi bawang lanang hitam (Alliun sativum L.) positif mengandung flavonoid, polifenol dan saponin yang dimungkinkan dapat berpotensi sebagai antidiabetes.

c. Uji Aktivitas Antidiabetes

Nilai $\left(\mathrm{EC}_{50}\right)$ digunakan untuk menguji potensi ekstrak umbi bawang lanang hitam (Alliun sativum L.) sebagai antidiabetes yang ditandai dengan adanya penurunan kadar glukosa. Penentuan penurunan kadar glukosa menggunakan metode Nelson-Somogyi yang secara khusus digunakan untuk mengetahui kadar gula pereduksi pada sampel (Al-kayyis \& Susanti, 2016).

\section{Operating time (Waktu Operasional)}

Hasil penelitian menunjukkan waktu optimum pada menit ke-23 sampai ke-26 dengan absorbansi stabil sebesar 0,703. Pada menit ke-23 hingga menit ke-26 disimpulkan bahwa reaksi yang terjadi telah sempurna. Hasil operating time sesuai dengan teoritis yaitu menit ke-25 (Wardatun dkk., 2016).

Panjang Gelombang Maksimum

Hasil dari pengukuran glukosa 20 ppm yang diukur pada rentang panjang gelombang 700-780 $\mathrm{nm}$ diperoleh panjang gelombang maksimum sebesar $746 \mathrm{~nm}$ dengan absorbansi 0,713. Pada Panjang gelombang tersebut diharapkan 
memberikan sensitivitas pengukuran tertinggi.

\section{Kontrol Positif}

Hasil rata-rata kontrol positif glukosa 20 ppm diperoleh absorbansi sebesar 0,737 . Data tersebut digunakan untuk mengetahui absorbansi glukosa utuh sebelum diberi perlakuan.

Uji Antidiabetes

Pengujian potensi aktivitas antidiabetes dilakukan untuk mengetahui kemapuan sampel ekstrak etanol umbi bawang lanang dalam menurunkan 50\% kadar Eglukosa baku. Sampel menggunakan 5 konsentrasi yaitu 1, 2, 3, 4 dan 5 ppm dari sampel ekstrak etanol umbi bawang lanang hitam 100 ppm untuk mengetahui nilai penurunan kadar glukosa yang dihasilkan.

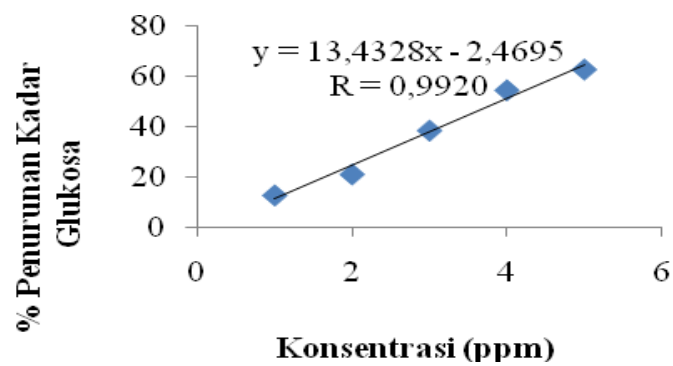

Gambar 1. \%`penurunan kadar glukosa dengan konsentrasi pengujian 1

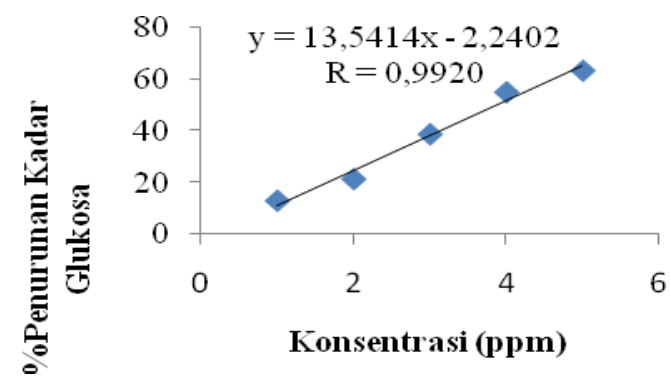

Gambar 2. \% penurunan kadar glukosa dengan konsentrasi pengujian 2

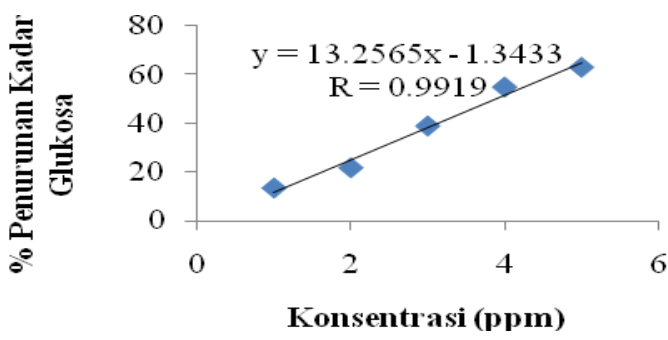

Gambar 3. \% penurunan kadar glukosa dengan konsentrasi pengujian 3

Berdasarkan grafik diatas menunjukkan terjadi penurunan kadar glukosa setelah pemberian perlakuan 5 konsentrasi sampel. Hasil persentase penurunan kadar glukosa pengujian 1, 2 dan 3 menunjukkan bahwa semakin tinggi konsentrasi perlakuan sampel yang diberikan akan semakin tinggi persentase penurunan kadar glukosa yang diperoleh. Nilai persentase penurunan kadar glukosa yang tinggi menunjukkan bahwa senyawa yang terkandung dalam umbi bawang lanang hitam banyak mengikat glukosa sehingga menghasilkan sisa glukosa yang bebas sedikit. Hal ini sesuai dengan penelitian (Anggraini \& Damayanti, 2019) dimana kandungan flavonoid yang terdapat pada ekstrak etanol kubis dan tomat dapat menurunkan kadar glukosa.

Senyawa umbi bawang lanang hitam (Allium sativum L.) yang dipercaya berfungsi dalam penurunan kadar glukosa adalah flavonoid. Hal initerjadi karena Gugus -OH pada flavonoid mampu mengikat glukosa sehingga kadar glukosa pada larutan akan menurun. Glukosa yang tidak terikat oleh senyawa pada umbi bawang lanang hitam disebut sisa glukosa yang akan bereaksi dengan reagen nelson untuk dapat mereduksi ion $\mathrm{Cu}^{2+}$ sehingga membentuk asam glukonat dan endapan $\mathrm{Cu}_{2} \mathrm{O}$ dari sisa glukosa. Pereaksi Nelson-Somogy mengandung Kalium natrium tartrat yang berfungsi menghambat pengendapan $\mathrm{Cu}_{2} \mathrm{O}$. Tabung reaksi ditutup kapas pada 
proses pemanasan agar reaksi berlangsung secara sempurna dan mempercepat reaksi reduksi kupri oksida menjadi kupro oksida. Proses pendinginan bertujuan agar reaksi berjalan stabil. Penambahan reagen arsenomolibdat agar endapan kupro oksida membentuk kompleks molibdenum yang berwarna biru kehijauan, lalu akan dibaca pada spektrofometri UV-Vis untuk menentukan nilai absorbansi yang diperoleh (Mutiara \& Wildan, 2014). Reaksi kimia yang terjadi terdapat pada gambar 4 dan 5 .

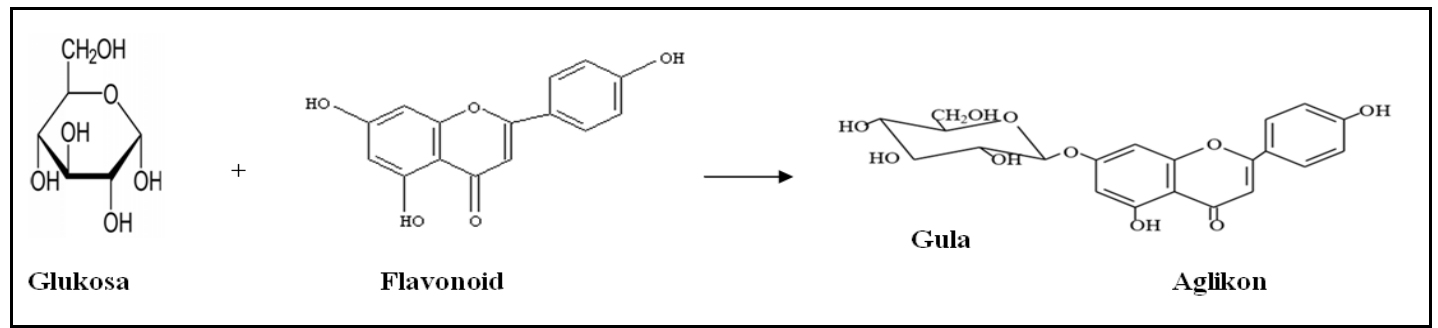

Gambar 4. Reaksi glukosa dengan flavonoid (Anggraini \& Damayanti, 2019)

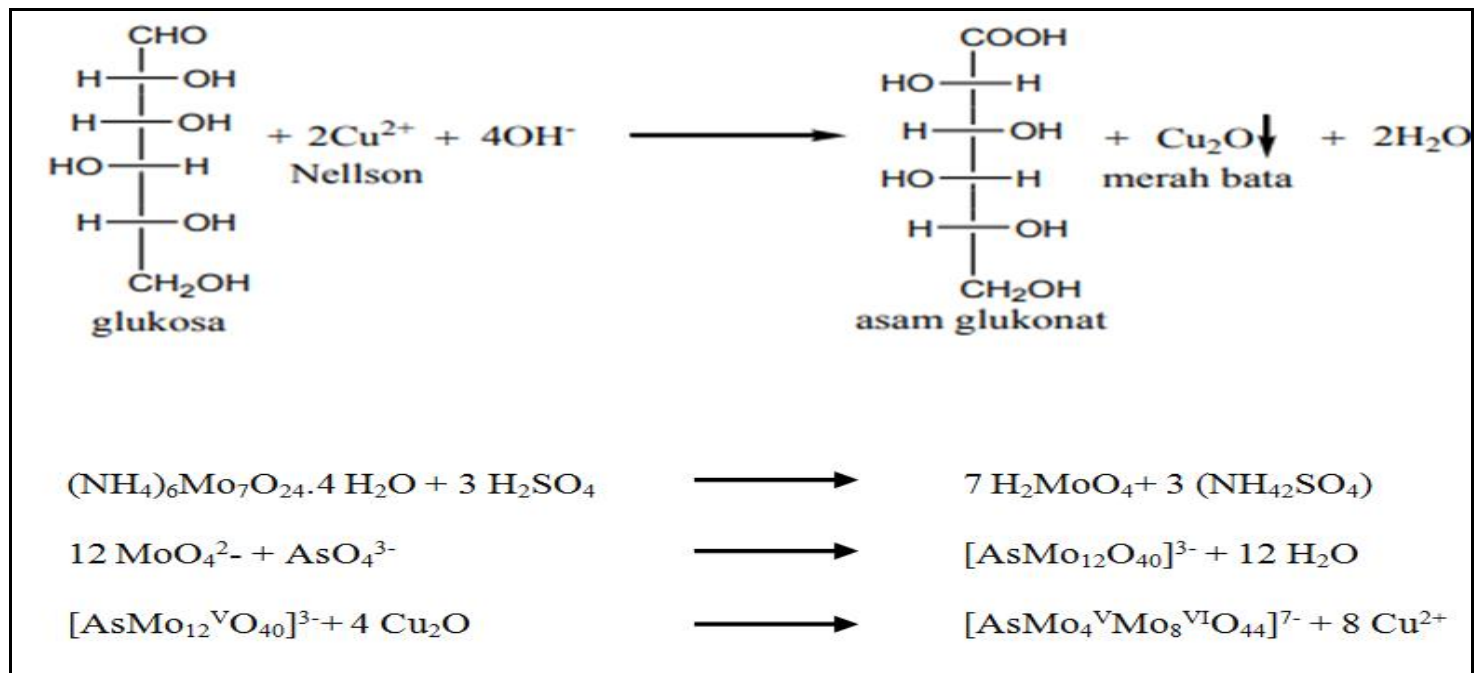

Gambar 5. Reaksi pembentukan senyawa kompleks glukosa dengan arsenomolibdat (Anggraini \& Damayanti, 2019) 
Pengukuran nilai $\mathrm{EC}_{50}$ dihitung menggunakan persamaan garis regresi linier. Hasil pengukuran nilai $\mathrm{EC}_{50}$ yang diperoleh tiga kali pengulangan pengujian ekstak etanol umbi bawang lanang hitam (Allium sativum L.) yaitu 3,9061 ppm; 3,8578 ppm dan 3,8731 ppm. Rata-rata nilai $\mathrm{EC}_{50}$ yang diperoleh yaitu 3,8790 ppm. Nilai $\mathrm{EC}_{50}$ sebesar $3,8790 \mathrm{ppm}$ artinya ekstrak etanol umbi bawang lanang hitam 3,8790 ppm yang menghasilkan $50 \%$ efek maksimal. Nilai $\mathrm{EC}_{50}$ senyawa uji tersebut mempunyai potensi sebagai penurun kadar glukosa. Menurut (Meila \& Noraini, 2017), ekstrak metanol buah kiwi (Actinidia deliciosa) yang mengandung flavonoid dan saponin mempunyai aktivitas antidiabetes dengan nilai $\mathrm{EC}_{50} 7,219$ ppm. Berdasarkan data diatas dapat disimpulkan bahwa ekstrak etanol umbi bawang lanang hitam (Allium sativum L.) mempunyai kemampuan antidiabetes lebih baik dibandingkan beberapa penelitian terdahulu.

Tabel 2. Hasil nilai $\mathrm{EC}_{50}$ dan $\% \mathrm{KV}$

\begin{tabular}{|c|c|c|c|}
\hline Sampel & Pengujian & $\begin{array}{l}\text { Nilai } \\
\text { EC }_{50}\end{array}$ & $\begin{array}{c}\text { Rata- } \\
\text { rata nilai } \\
\text { EC }_{50}\end{array}$ \\
\hline \multirow{3}{*}{$\begin{array}{l}\text { Ekstrak } \\
\text { etanol } \\
\text { umbi } \\
\text { bawang } \\
\text { lanang } \\
\text { hitam }\end{array}$} & 1 & $\begin{array}{c}3,9061 \\
\mathrm{ppm}\end{array}$ & \multirow{3}{*}{$\begin{array}{c}3,8790 \\
\text { Ppm }\end{array}$} \\
\hline & 2 & $\begin{array}{c}3,8578 \\
\text { ppm }\end{array}$ & \\
\hline & 3 & $\begin{array}{c}3,8731 \\
\mathrm{ppm}\end{array}$ & \\
\hline
\end{tabular}

$\% \mathrm{KV}$ atau koefisien variasi adalah pemeriksaan berulang pada sampel yang sama (akurasi). Nilai koefisien variasi dari data pengujian 1,2 dan 3 adalah $0,6368 \%$. Penelitian ini diperoleh nilai koefisien variasi yang memenuhi persyaratan yaitu kurang dari $2 \%$ (Harmita, 2004). Semakin kecil persentase koefisien variasi yang diperoleh menunjukkan ketelitian yang baik.

\section{KESIMPULAN}

Hasil penelitian yang dilakukan ekstrak etanol umbi bawang lanang hitam (Allium sativum L.) menghasilkan nilai $\mathrm{EC}_{50}$ sebesar 3,8790 ppm yang memiliki potensi penurunan kadar glukosa.

\section{REFERENSI}

Al-Kayyis, H. K., \& Susanti, H. (2016). Perbandingan Metode Somogyi-Nelson Dan Anthrone-Sulfat Pada Penetapan Kadar Gula Pereduksi Dalam Umbi Cilembu (Ipomea Batatas L.). Journal of Pharmaceutical Sciences And Community, 13(02), 81-89. Https://Doi.Org/10.24071/Jpsc.2016.130206

Amelia, W., Alisa, F., Sastra, L., \& Despitasari, L. (2020). Edukasi Online Pelaksanaan Aktifitas Fisik Pada Pasien Diabetes Melitus Di Masa Pandemi Covid19. Celebes Abdimas: Jurnal Pengabdian Kepada Masyarakat, 2(2), 53-57. Https://Doi.Org/10.37541/Celebesabdimas. V2i2.451

Anggraini, D. I., \& Damayanti, D. (2019). Studi Antidiabetes Kombinasi Ekstrak Etanol Kubis (Brassica Oleracea L.) Dan Tomat (Solanum Lycopersicum L.) Secara In Vitro. Jurnal Ilmiah As-Syifaa, 11(1), 3037.

Armin, F., \& Dewi, Y. Y. (2011). Penentuan Kadar Senyawa Fenolat Dan Uji Aktivitas Antioksidan Pada Buah Terung Belanda (Cyphomandra Betacea (Cav.). 3(1), 15.

Handarini, K. (2014). Potensi Ekstrak Bunga Rosella (Hibiscus Sabdariffa L.) Sebagai Pewarna Dan Pengawet Alami Pada Jelly Jajanan Anak. Heuristic, 11(02).

Harmita, H. (2004). Petunjuk Pelaksanaan Validasi Metode Dan Cara Perhitungannya. Majalah Ilmu Kefarmasian, 1(3), 117-135. Https://Doi.Org/10.7454/Psr.V1i3.3375

Huang, C., Wang, Y., Li, X., Ren, L., Zhao, J., Hu, Y., Zhang, L., Fan, G., Xu, J., Gu, X., Cheng, Z., Yu, T., Xia, J., Wei, Y., Wu, W., Xie, X., Yin, W., Li, H., Liu, M., ... Cao, B. (2020). Clinical Features Of Patients Infected With 2019 Novel Coronavirus In 
Wuhan, China. The Lancet, 395(10223), 497-506. Https://Doi.Org/10.1016/S01406736(20)30183-5

Kimura, S., Tung, Y.-C., Pan, M.-H., Su, N.W., Lai, Y.-J., \& Cheng, K.-C. (2017). Black Garlic: A Critical Review Of Its Production, Bioactivity, And Application. Journal Of Food And Drug Analysis, 25(1), 62-70.

Https://Doi.Org/10.1016/J.Jfda.2016.11.003

Meila, O., \& Noraini, N. (2017). Uji Aktivitas Antidiabetes Dari Ekstrak Metanol Buah Kiwi (Actinidia Deliciosa) Melalui Penghambatan Aktivitas A-Glukosidase. Jurnal Farmasi Galenika (Galenika Journal Of Pharmacy)(E-Journal), 3(2), 132-137.

Mutiara, E. V., \& Wildan, A. (2014). Ekstraksi Flavonoid Dari Daun Pare (Momordica Charantia L.) Berbantu Gelombang Mikro Sebagai Penurun Kadar Glukosa Secara In Vitro. METANA, 10(01),
$1-11$.

Https://Doi.Org/10.14710/Metana.V10i01.9 771

Wang, W., Lu, J., Gu, W., Zhang, Y., Liu, J., \& Ning, G. (2020). Care For Diabetes With COVID-19: Advice From China. Journal of Diabetes, 12(5), 417-419. Https://Doi.Org/10.1111/1753-0407.13036

Wardatun, S., Yulia, I., \& Aprizayansyah, A. (2016). Kandungan Flavonoid Ekstrak Metanol Dan Ekstrak Etil Asetat Daun Sukun (Artocarpus Altilis (Park.) Fosberg) Dan Aktivitasnya Terhadap Penurunan Kadar Glukosa Secara In Vitro. Fitofarmaka: Jurnal Ilmiah Farmasi, 6(2), 52-63.

Https://Doi.Org/10.33751/Jf.V6i2.754

Zhafira, R. (2019). Pengaruh Lama Aging Terhadap Sifat Fisik, Kimia, Dan Aktivitas Antioksidan Produk Bawang Hitam Lanang. Jurnal Pangan Dan Agroindustri, 6(1). 